\title{
MIR32 Gene
}

National Cancer Institute

\section{Source}

National Cancer Institute. MIR32 Gene. NCI Thesaurus. Code C81763.

This gene is involved in the regulation of gene expression and plays a role in the development of plasma cell myeloma. 